\title{
TELAAH KONFLIK DALAM NOVEL MOGA BUNDA DISAYANG ALLAH KARYA TERE LIYE
}

\author{
Yuliniarti \\ SMAN 6 Bengkulu Tengah \\ yuli.niarti@gmail.com
}

\begin{abstract}
Abstrak
Rumusan masalah adalah bagaimanakah konflik-konflik, faktor penyebab konflik, dan penyelesaian konflik yang terdapat dalam novel Moga Bunda Disayang Allah karya Tere Liye bertujuan untuk mendeskripsikan cara pengungkapan tuturan atau kesantunan pada masyarakat Rejang Pesisir dan konflik-konflik, faktor penyebab konflik, dan penyelesaian konflik yang terdapat dalam novel Moga Bunda Disayang Allah karya Tere Liye. Metode penelitian yang digunakan adalah metode deskriptif. Dari hasil penelitian ini ditemukan bahwa (1) jenis konflik yang terdapat dalam novel Moga Bunda Disayang Allah karya Tere-Liye terdiri dari konflik internal dan konflik eksternal. Terdapat 12 konflik, yang terdiri dari 5 berbentuk konflik internal dan 7 konflik eksternal, (2) faktor penyebab terjadinya konflik dalam novel Moga Bunda Disayang Allah karya Tere-Liye terdiri dari perbedaan individu, yang meliputi perbedaan pendirian dan perasaan, perbedaan latar belakang kebudayaan sehingga membentuk pribadi-pribadi yang berbeda, perbedaan kepentingan antara individu atau kelompok, dan perubahan nilai yang cepat dan mendadak dalam masyarakat, dan (3) alternatif pemecahan yang ditawarkan pengarang terhadap konflik yang terdapat dalam novel Moga Bunda Disayang Allah karya Tere-Liye, penekanan atau dominasi terhadap suatu pihak menjadi alternatif yang banyak digunakan pengarang. Disamping itu terdapat pemecahan masalah secara kompromi. Pada bagian akhir, penyelesaian konflik menggunakan pemecahan secara integratif.
\end{abstract}

Kata kunci : Konflik, novel Moga Bunda Disayang Allah

\begin{abstract}
The formulation of the problem is how the conflicts, the causes of conflict, and the resolution of conflicts contained in the novel Moga Bunda Disayang Allah by Tere Liye aims to describe how to express utterance or politeness in the Coastal Rejang community and conflicts, the factors causing conflict, and conflict resolution. contained in the novel Moga Bunda Disayang Allah by Tere Liye. The method used is descriptive method. From the results of this study it was found that (1) the types of conflicts contained in the novel Moga Bunda Disayang Allah by Tere-Liye consist of internal conflicts and external conflicts. There are 12 conflicts, which consist of 5 forms of internal conflict and 7 external conflicts, (2) the causes of conflict in the novel Moga Bunda Disayang Allah by Tere-Liye consist of individual differences, which include differences in stance and feelings, differences in cultural backgrounds so forming different personalities, differences in interests between individuals or groups, and rapid and sudden changes in values in society, and (3) alternative solutions offered by the author of conflicts in the novel Moga Bunda Disayang Allah by Tere-Liye, emphasis or domination of a party becomes an alternative that is widely used by the author. Besides that there is a compromise problem solving. At the end, conflict resolution uses integrative solution.
\end{abstract}

Keywords: Conflict, novel Moga Bunda Loved by Allah

\section{PENDAHULUAN}

Karya sastra merupakan miniatur kehidupan yang digali dalam spektrum kebudayaan yang mekar dari suatu komunitas masyarakat. Sebagai suatu hasil karya seni sastra mempunyai kedudukan yang sama dengan karya seni yang lain. Karya sastra bagi pengarangnya tentu merupakan suatu jalan untuk mengungkapkan ide-ide, pikiran atau perasaannya. Pengungkapan semua hal di atas menggunakan alat, media atau sarana bahasa. Namun, satu hal yang perlu diingat bahwa bahasa yang digunakan oleh sastrawan tidak sama dengan bahasa yang digunakan dalam tindak komunikasi sehari-hari. Bahasa sastra sering bermakna konotatif dan oleh sebab itu suatu karya sastra mengandung banyak kemungkinan arti (Semi, 1988:8). 
Karya sastra diciptakan oleh sastrawan untuk dinikmati, dipahami dan dimanfaatkan oleh masyarakat. Sastrawan sebagai pencipta karya sastra mengharapkan hasil karyanya dapat dinikmati oleh pembaca. Salah satunya jenis sastra yang diciptakan oleh sastrawan adalah novel.

Karya sastra berupa novel berusaha menyampaikan pesan kepada pembacanya mengenai sebuah hikmah yang dikemas dalam bentuk peristiwa dalam ceritanya. Nurgiyantoro (2002:4) menjelaskan sebagai sebuah karya sastra fiksi, novel menawarkan sebuah dunia, dunia yang berisi model kehidupan yang diidealkan.

Telaah konflik yang dialami tokoh dalam sebuah karya sastra dapat meningkatkan pemahaman pada nilai-nilai pendidikan yang tercipta dari karya sastra. Hasil pemahaman pada penyebab konflik, bentuk konflik dan penanganan konflik dapat pula memberikan petunjuk pembaca dalam menghadapi cobaan, memahami dan menghayati suatu kejadian serta menyelesaikan suatu persoalan (konflik).

Telaah terhadap konflik yang terdapat dalam novel Moga Bunda Disayang Allah karya Tere Liye dapat memberikan nilai petunjuk dan pemahaman penanganan konflik sesuai kejadian yang ditunjukkan dalam cerita pada novel Moga Bunda Disayang Allah karya Tere Liye.

Istilah kajian, atau pengkajian, yang dipergunakan dalam mengarah pada pengertian penelaahan, penyelidikan. Ia merupakan pembendaan dari perbuatan mengkaji, menelaah atau menyelidiki (meneliti). Pengkajian terhadap karya fiksi berarti penelaahan, penyelidikan, atau mengkaji, menelaah, menyelidiki karya fiksi tersebut (Nurgiyantoro, 2010:30). Untuk melakukan pengkajian terhadap unsur-unsur pembentuk karya sastra, khususnya fiksi, pada umumnya kegiatan ini disertai oleh kerja analisis.

Apa yang diartikan dan dimaksudkan dengan pengkajian sastra ialah penyelidikan atau penelitian dengan menelaah suatu karya sastra. Dalam pengkajian melibatkan aspek penerimaan dan penafsiran. Rekais langsung atau tidak langsung dari pembaca adalah penerimaan (resepsi) dari teks yang merupakan bahan bacaan yang dijadikan teks konkret sesuai dengan pengertian, pengalaman dan penghayatan pembaca. Penafsiran adalah bentuk khusus mengenai laporan penerimaan. Penafsiran, penilaian dan penghakiman terhadap karya sastra disebut kritik sastra (Pradotokusumo, 2008:55).

Rafiek (2013:2) menjelaskan pengkajian sastra adalah mengkaji sastra secara mendalam dengan menggunakan teori sastra dan teknik analisis sastra yang tepat. Mengkaji sastra berarti menelaah karya sastra dengan menganalisis dan membahas data-data berupa kutipan kalimat atau paragraf yang mengandung masalah atau topik yang hendak kita jawab atau uraikan.

Menurut Nurgiyantoro (2010:122) konflik merupakan kejadian yang tergolong penting, merupakan unsur yang esensial dalam pengembangan plot. Pengembangan plot sebuah karya naratif akan dipengaruhi oleh wujud dan isi konflik, bangunan konflik yang ditampilkan. 97| http://jurnal.umb.ac.id/index.php/lateralisasi 
Konflik mengarah pada pengertian sesuatu yang bersifat tidak menyenangkan yang menjadi dan atau dialami oleh tokoh cerita.

Konflik adalah sesuatu yang dramatik, mengacu pada pertarungan antara dua kekuatan yang seimbang dan menyiratkan adanya aksi dan aksi balasan (Wellek dan Warrren dalam Nurgiyantoro, 2010:122). Konflik, dengan demikian dalam pandangan kehidupan yang normal wajar faktual, artinya bukan dalam cerita, mengarah pada konotasi negatif, sesuatu yang tidak menyenangkan. Itulah sebabnya orang lebih suka memilih menghindari konflik dan menghendaki kehidupan yang tenang. Konflik merupakan bentuk kejadian atau periistiwa. Menurut Stanto (dalam Nurgiyantoro, 2010:124) konflik dapat dibedakan kedalam dua kategori yakni konflik fisik dan konflik batin, konflik eksternal (external conflict) dan konflik internal (internal conflict).

Penyelesaian konflik dalam cerita rekaan menurut Widoyoko (dalam Risniara, 2013:16) dilakukan dengan mengurangi konflik dan dengan menyelesaikan konflik. Metode pengurangan konflik merupakan salah satu metode yang efektif dengan cara membandingkan persoalan terlebih dahulu. Meskipun demikian, cara semacam ini belum menyentuh persoalan sebenarnya. Cara kedua dengan penyelesaian konflik, cara yang ditempuh adalah dengan mendominasi atau menekan, berkompromi dan penyelesaian masalah secara intergratif.

Penelitian ini fokus pada struktur novel Moga Bunda Disayang Allah karya Tere Liye, khususnya unsur konflik sebuah novel. Konflik dalam sebuah novel berkaitan erat dengan unsur penokohan, tema dan alur. Dikaitkan dengan penokohan, karena setiap konflik dialami oleh tokoh. Tema merupakan gambaran umum yang hendak disampaikan penulis melalui sejumlah konflik dan penyelesaiannya. Konflik juga berkaitan dengan alur, karena konflik merupakan bagian dari alur. Serta faktor apakah yang menyebabkan terjadinya konflik dan penyelesaian konflik dalam novel Moga Bunda Disayang Allah karya Tere Liye.

\section{METODE PENELITIAN}

Penelitian ini didesain sebagai penelitian deskriptif. Penelitian deskriptif digunakan untuk mendapatkan gambaran suatu keadaan yang berlangsung sekarang. Data dalam penelitian ini adalah konflik yang terdapat dalam novel Moga Bunda Disayang Allah karya Tere-Liye. Data dirinci ke, data faktor-faktor penyebab terjadinya konflik dan data alternatif pemecahan konflik yang ditawarkan oleh penulis.

\section{HASIL PENELITIAN DAN PEMBAHASAN}

\section{Jenis Konflik}

Novel Moga Bunda Disayang Allah karya Tere-Liye terdiri dari 15 bagian. Berikut adalah gambaran jenis konflik yang terjadi dalam novel tersebut. 
Tabel 1 Jenis Konflik dalam Novel Moga Bunda Disayang Allah karya Tere-Liye

\begin{tabular}{|c|l|c|c|}
\hline \multirow{2}{*}{ Bagian } & \multicolumn{1}{|c|}{ Judul } & \multicolumn{2}{|c|}{ Jenis Konflik } \\
\cline { 3 - 4 } & & Internal & Eksternal \\
\hline $\mathbf{1}$ & Jeruk manis spesial & $\sqrt{ }$ & \\
\hline $\mathbf{2}$ & Merah kuning hijau & & $\sqrt{ }$ \\
\hline $\mathbf{3}$ & Ribuan kunang-kunang & $\sqrt{ }$ & \\
\hline $\mathbf{4}$ & Tiga tahun lalu & & $\sqrt{ }$ \\
\hline $\mathbf{5}$ & Keterbatasan Melati & & $\sqrt{ }$ \\
\hline $\mathbf{6}$ & Pertemuan pertama & & $\sqrt{ }$ \\
\hline $\mathbf{7}$ & Satu minggu berlalu & & $\sqrt{ }$ \\
\hline $\mathbf{8}$ & Gadis lesung pipit & & \\
\hline $\mathbf{9}$ & Kursi, kursi, kursi & $\sqrt{ }$ & \\
\hline $\mathbf{1 0}$ & Gadis berkerudung lembut & & \\
\hline $\mathbf{1 1}$ & Boneka Panda & & \\
\hline $\mathbf{1 2}$ & Tarian aurora & & \\
\hline $\mathbf{1 3}$ & Keajaiban telapak tangan & & \\
\hline $\mathbf{1 4}$ & Fertival kembang api & & \\
\hline $\mathbf{1 5}$ & Epilog & & \\
\hline
\end{tabular}

Pada bagian 1 sampai 15, ditemukan sebanyak 12 konflik, yang terdiri dari 5 berbentuk konflik internal dan 7 konflik eksternal. Data lengkap dapat dilihat pada lampiran.

Temuan-temuan jenis konflik yang terjadi dalam novel Moga Bunda Disayang Allah karya Tere-Liye berikutnya diidentifikasi untuk dilihat tata urut konflik atau rentetan konflik yang dialami oleh para tokoh dalam cerita. Berikut gambaran khusus konflik hasil temuan dalam novel Moga Bunda Disayang Allah karya Tere-Liye:

Tabel 2 Gambaran Khusus Jenis Konflik dalam Novel Moga Bunda Disayang Allah karya Tere-Liye

\begin{tabular}{|c|c|c|c|}
\hline \multirow{2}{*}{ Bagian } & \multicolumn{2}{|c|}{ Jenis Konflik } & \multirow{2}{*}{ Keterangan } \\
\hline & Internal & Eksternal & \\
\hline 1 & $\sqrt{ }$ & & $\begin{array}{l}\text { Bagian } 1 \text { diawali dengan konflik } \\
\text { internal yang dialami Bunda. Terlihat di } \\
\text { halaman } 9 .\end{array}$ \\
\hline 2 & $\sqrt{ }$ & & $\begin{array}{l}\text { Bagian ini mengurai konflik internal } \\
\text { Karang. Terlihat pada halaman 20, } 24 \\
\text { dan } 30 \text {. }\end{array}$ \\
\hline 3 & & $\sqrt{ }$ & $\begin{array}{l}\text { Penulis mengenalkan konflik eksternal. } \\
\text { Terlihat pada halaman } 38 \text { dan } 40 \text {. }\end{array}$ \\
\hline 4 & $\sqrt{ }$ & & $\begin{array}{l}\text { Penulis kembali mengurai kisah konflik } \\
\text { internal Karang. Halaman 70-71. }\end{array}$ \\
\hline 5 & & $\sqrt{ }$ & $\begin{array}{l}\text { Bagian ini berisikan konflik eksternal } \\
\text { Karang dan ibu-ibu gendut. halaman 91- } \\
\text { 92. }\end{array}$ \\
\hline 6 & & $\sqrt{ }$ & $\begin{array}{l}\text { Menguraikan konflik eksternal Karang, } \\
\text { dan Tuan HK. Halaman 102, dan } 114 .\end{array}$ \\
\hline 7 & & $\sqrt{ }$ & $\begin{array}{l}\text { Terdiri dari uraian-uraian konflik } \\
\text { eksternal yang terjadi secara beruntun. } \\
\text { Halaman } 128,129,134,135,142 \text {, dan }\end{array}$ \\
\hline
\end{tabular}




\begin{tabular}{|c|c|c|l|}
\hline & & & 143. \\
\hline $\mathbf{8}$ & & $\sqrt{ }$ & $\begin{array}{l}\text { Bagian ini berisi konflik eksternal. } \\
\text { Halaman 160, 166 dan 170. }\end{array}$ \\
\hline $\mathbf{9}$ & $\sqrt{ }$ & & $\begin{array}{l}\text { Bagian ini mengurai konflik internal } \\
\text { tokoh. Halaman 190, dan 203. }\end{array}$ \\
\hline $\mathbf{1 0}$ & & $\sqrt{ }$ & $\begin{array}{l}\text { Konflik eksternal terjadi di bagian ini. } \\
\text { Halaman 207 dan 210. }\end{array}$ \\
\hline $\mathbf{1 2}$ & $\sqrt{13}$ & & $\begin{array}{l}\text { Konflik internal pada bagian ini. } \\
\text { Halaman 244, dan 254. }\end{array}$ \\
\hline $\begin{array}{l}\text { Bagian ini mengraui konflik eksternal, } \\
\text { pada halaman 266 dan 276. }\end{array}$ \\
\hline
\end{tabular}

Secara keseluruhan konflik yang terdapat dalam novel Moga Bunda Disayang Allah karya Tere-Liye didominasi oleh konflik eksternal. Konflik eksternal terdapat pada bagian 3, 5, 6, 7, 8, 10, dan 13. Sementara konflik internal terdapat pada bagian 1, 2, 4, 9 dan 12.

\section{Faktor Penyebab Konflik}

1. Faktor Perbedaan individu

Konflik yang terjadi akibat adanya perbedaan individu ini terlihat pada konflik yang terjadi pada halaman 9, 24, 40, 129, 148, dan 203.

2. Faktor Perbedaan latar belakang, kebudayaan

Konflik-konflik yang disebabkan adanya perbedaan latar belakang kebudayaan antara lain terdapat pada konflik yang terjadi pada halaman 70, 114, 160, 166, 254, dan 266.

3. Faktor Perbedaan kepentingan antara individu atau kelompok.

Konflik-konflik yang disebabkan adanya perbedaan kepentingan antara individu atau kelompok yakni terdapat pada halaman 91, 170, dan 190.

4. Faktor Perubahan-perubahan nilai yang cepat dan mendadak

Konflik-konflik yang disebabkan adanya perubahan-perubahan nilai yang cepat dan mendadak yakni pada halaman 20, 30, 38, 102, 128, 134, 135, 142, 143, 207, 210, 244.

\section{Penyelesaian Konflik}

Hasil inventarisasi alternatif yang ditawarkan pengarang dalam menyelesaikan konflik dalam novel Moga Bunda Disayang Allah karya Tere-Liye:

Tabel 3 Alternatif Pemecahan Masalah yang Ditawarkan Pengarang

\begin{tabular}{|l|l|c|}
\hline No & \multicolumn{1}{|c|}{ Alternatif Pemecahan } & Halaman \\
\hline 1. & Penekanan suatu pihak & 22 \\
2. & Penekanan suatu pihak & 25 \\
3. & Penekanan suatu pihak & 31 \\
4. & Penekanan suatu pihak & 39 \\
5. & Penekanan suatu pihak & 41 \\
6. & Penekanan suatu pihak & 71 \\
7. & Penekanan suatu pihak & 92 \\
8. & Penekanan suatu pihak & 108 \\
\hline
\end{tabular}




\begin{tabular}{|l|l|l|}
\hline 9. & Penekanan suatu pihak & 117 \\
10. & Penekanan suatu pihak & 128 \\
11. & Penekanan suatu pihak & 129 \\
12. & Penekanan suatu pihak & 135 \\
13. & Penekanan suatu pihak & 144 \\
14. & Penekanan suatu pihak & 149 \\
15. & Penekanan suatu pihak & 161 \\
16. & Penekanan suatu pihak & 167 \\
17. & Penekanan suatu pihak & 175 \\
18. & Pemecahan secara integratif & 204 \\
19. & Penekanan suatu pihak & 208 \\
20. & Pemecahan secara integratif & 212 \\
21. & Kompromi & 246 \\
22. & Pemecahan secara integratif & 255 \\
23. & Pemecahan secara integratif & 271 \\
\hline
\end{tabular}

Alur konflik yang terjadi dalam novel Moga Bunda Disayang Allah karya Tere-Liye digambarkan sebagai berikut:

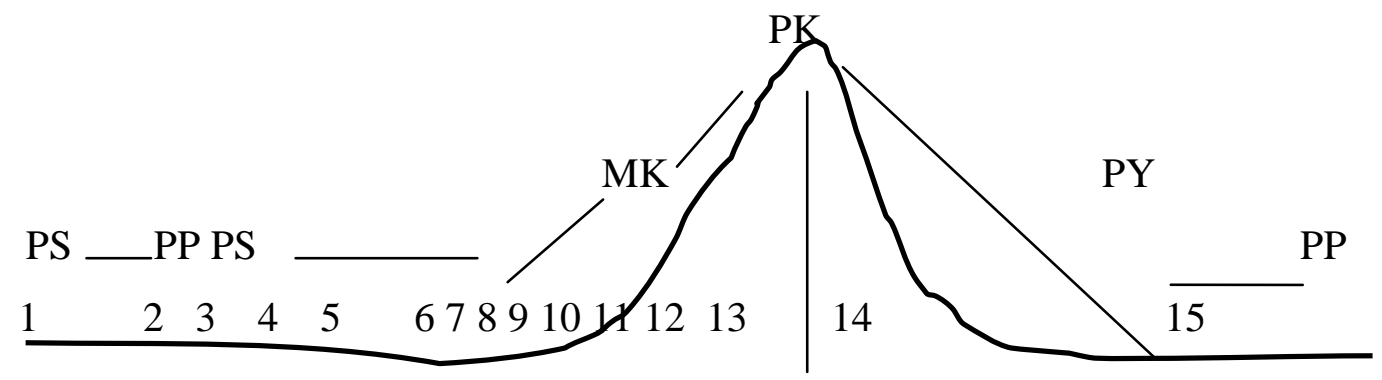

Keterangan:

PS = Pengenalan situasi

$\mathrm{PP} \quad=$ Pengenalan peristiwa

MK = Menuju konfik

PK = Puncak konflik

$\mathrm{PY} \quad=$ Penyelesaian

Sesuai gambar alur di atas, tahapan cerita pada novel Moga Bunda Disayang Allah karya Tere-Liye terdiri dari:

1. Pengenalan situasi cerita (exposition) diuraikan penulis pada Bab 1 Jeruk Manis Spesial. Bagian ini dikenalkan tokoh-tokoh cerita seperti Bunda, Melati dan Karang. Pada bagian ini dikenalkan situasi atau setting cerita. Pengungkapan situasi ini kembali diceritakan penulis pada Bab 3.

2. Pengungkapan peristiwa (complication) diuraikan penulis pada Bab 2 sampai dengan Bab 6, dimana antar tokoh saling bertemu ketika semuanya berusaha dalam penyembuhan Melati sebagai peristiwa awal yang akan menimbulkan masalah dan pertentangan antar tokoh. Dalam pengungkapan peristiwa ini penulis menggambarkan awal mula terjadinya peristiwa, konflik atau latar pertemuan antar tokoh. 
3. Menuju konflik (rising action) penulis memulai peristiwa-peristiwa pertentangan antar tokoh yakni Bunda, Karang, Melati dan Tuan HK serta Ibu gendut, dan situasi yang semakin rumit pada Bagian 7 sampai dengan 12. Penulis secara terus-menerus menggiring cerita pada tingkat konflik yang semakin rumit. Oleh sebab itu intensitas konflik yang terjadi antar tokoh semakin meningkat.

4. Puncak konflik (turning point). Merupakan klimaks cerita. Konflik besar terjadi antara Karang, Tuan HK dan Bunda dengan emosi dan kemarahan memuncak dari Tuan HK kepada Karang dan Bunda. Klimaks ini terjadi pada Bagian 13.

Konflik utama dalam novel Moga Bunda Disayang Allah karya Tere-Liye ditemukan pada halaman 266. Yakni Karang yang pemabuk dan caranya dalam mendidik Melati, membuat Tuan HK mengusir Karang. Disisi lain pandangan Bunda tentang kemampuan Karang dalam mendidik anak-anak membuat Bunda mempertahankan Karang, dan berharap banyak pada kemampuan Karang untuk membantu anaknya.

“KAU!! PERGI DARI RUMAH INI!” tuan HK Beringas melangkah mendekati kursi Karang. Buku-buku tinjunya terlihat. Wajahnya memerah oleh amarah” Bunda gagap segera melangkah mencegah suaminya.

"Jangan, Yang.... Jangan!”

"BAGAIMANA MUNGKIN KAU MEMBOHONGIKU?? Tuan HK membentak istrinya. Ia benar-benar tidak terkendali sekarang” (SBDA, 2011:266).

5. Penyelesaian (ending). Bagian ini terdapat pada Bagian 14 dan 15 dimana konflik yang terjadi selesai ketika terdapat kemajuan pada kesehatan Melati dan semua tokoh cerita merasa gembira dan mendukung usaha yang selama ini dipertentangkan. Pada bagian ini penulsi menyelesaikan konflik secara intergratif, dimana semua pihak terlibat secara langsung atau tidak langsung dalam menurunkan konflik, serta harapan yang menjadi persoalan cerita diwujudkan dengan adanya kemajuan pada kesehatan Melati. Sehingga semua tokoh yang terlibat konflik dalam tujuan dan harapan menyembuhkan Melati menemukan kebahagiaan di bagian akhir cerita.

\section{SIMPULAN}

Berdasarkan hasil penelitian dan pembahasan di atas, maka dapat diperoleh kesimpulan sebagai berikut:

1. Jenis konflik yang terdapat dalam novel Moga Bunda Disayang Allah karya Tere-Liye terdiri dari konflik internal dan konflik eksternal. Terdapat 12 konflik, yang terdiri dari 5 berbentuk konflik internal dan 7 konflik eksternal.

2. Faktor penyebab terjadinya konflik dalam novel Moga Bunda Disayang Allah karya TereLiye terdiri dari perbedaan individu, yang meliputi perbedaan pendirian dan perasaan, perbedaan latar belakang kebudayaan sehingga membentuk pribadi-pribadi yang berbeda, 
perbedaan kepentingan antara individu atau kelompok, dan perubahan nilai yang cepat dan mendadak dalam masyarakat.

3. Alternatif pemecahan yang ditawarkan pengarang terhadap konflik yang terdapat dalam novel Moga Bunda Disayang Allah karya Tere-Liye, penekanan atau dominasi terhadap suatu pihak menjadi alternatif yang banyak digunakan pengarang. Disamping itu terdapat pemecahan masalah secara kompromi. Pada bagian akhir, penyelesaian konflik menggunakan pemecahan secara integratif.

\section{DAFTAR PUSTAKA}

Aminuddin. (2004). Pengantar Apresiasi Karya Sastra. Bandung: Sinar Baru.

Arikunto, Suharsimi. (2006). Prosedur Penelitian: Suatu Pendekatan Praktis. Jakarta: Rineka Cipta.

Atmazaki. (2006). Kiat-kiat Mengarang dan Menyunting. Padang: Yayasan Citra Budaya.

Endraswara, Suwardi. (2008). Metode Penelitian Psikologi Sastra. Yogyakarta: Media Press.

Fanane, Zainudin. (2000). Telaah Sastra. Surakarta: Muhammadiyah University Press.

Kosasih, E. (2012). Dasar-Dasar Keterampilan Bersastra. Bandung: Yarma Widya.

Moleong, J Lexy. (2005). Metodologi Penelitian Kualitatif. Bandung: Remaja Rosda Karya.

Muhardi dan Hasanuddin. (1992). Prosedur Analisis Fiksi. Padang: IKIP Padang Press.

Nurgiyantoro, Burhan. (1995). Teori Pengkajian Fiksi. Yogyakarta: UGM Press.

Pradopo, Rachmat Djoko. (2002). Kritik Sastra Indonesia Moderen. Yogyakarta: Gamma Media.

Putra, Bambang Adi. (2014). Analisis Alur dalam Novel Pesan dari Sambu Karangan Tasmi, P.S. (Universitas Muhammadiyah Bengkulu: Skripsi). Tidak Diterbitkan.

Ratna, Nyoman Kutha. (2004). Teori, Metode, dan Teknik Penelitian Sastra. Yogyakarta: Pustaka Belajar.

Risniara. (2013). Telaah Konflik dalm Novel Bumi Cinta karya Habiburrahman El-Shirazy. (Universitas Bengkulu: Tesis). Tidak Diterbitkan.

Semi, Atar. (1998). Metode Penelitian Sastra. Bandung: Angkasa Raya.

Sugiyono. (2012). Metodologi Penelitian Pendidikan. Bandung: Alfabetha.

Tarigan, Guntur. (1986). Prinsip-Prinsip Dasar Sastra. Bandung: Angkasa.

Teeuw, A. (1984). Sastra dan Ilmu Sastra: Pengantar Teori Sastra. Jakarta: Pustaka Jaya.

Tere-Liye. (2013). Moga Bunda Disayang Allah. Jakarta: Republika.

103| http://jurnal.umb.ac.id/index.php/lateralisasi 